\title{
Radiolabeling with fluorine-18 of a protein, interleukin-1 receptor antagonist
}

\author{
C. Prenant ${ }^{\mathrm{a}, *, 1}$, C. Cawthorne ${ }^{\mathrm{b}}$, M. Fairclough ${ }^{\mathrm{a}}$, N. Rothwell ${ }^{\mathrm{c}}$, H. Boutin $^{\mathrm{c}}$ \\ ${ }^{a}$ Wolfson Molecular Imaging Centre, University of Manchester, Manchester, UK \\ ${ }^{\mathrm{b}}$ Academic Department of Radiation Oncology, The Christie NHS Foundation Trust, Manchester, UK \\ ${ }^{\mathrm{c}}$ Faculty of Life Sciences, University of Manchester, Manchester, UK
}

\section{A R T I C L E I N F O}

\section{Article history:}

Received 16 December 2009

Received in revised form

26 February 2010

Accepted 1 April 2010

Keywords:

$\left[{ }^{18} \mathrm{~F}\right]$ rhIL-1RA

IL-1

Inflammation

$\left[{ }^{18} \mathrm{~F}\right]$ fluoroacetaldehyde

PET.

\begin{abstract}
A B S T R A C T
IL-1RA is a naturally occurring antagonist of the pro-inflammatory cytokine interleukin-1 (IL-1) with high therapeutic promise, but its pharmacokinetic remains poorly documented. In this report, we describe the radiolabeling of recombinant human interleukin-1 receptor antagonist (rhIL-1RA) with fluorine-18 to allow pharmacokinetic studies by positron emission tomography (PET). rhIL-1RA was labeled randomly by reductive alkylation of free amino groups (the $\varepsilon$-amino group of lysine residues or amino-terminal residues) using $\left[{ }^{18} \mathrm{~F}\right]$ fluoroacetaldehyde under mild reaction conditions. Radiosyntheses used a remotely controlled experimental rig within $100 \mathrm{~min}$ and the radiochemical yield was in the range 7.1-24.2\% (decay corrected, based on seventeen syntheses). We showed that the produced $\left[{ }^{18} \mathrm{~F}\right]$ fluoroethyl-rhIL-1 ra retained binding specificity by conducting an assay on rat brain sections, allowing its pharmakokinetic study using PET.

(c) 2010 Elsevier Ltd. All rights reserved.
\end{abstract}

\section{Introduction}

The pro-inflammatory cytokine IL-1 plays an important role in inflammation, angiogenesis, and the immune response (Dinarello, 1988, 1997) and has been implicated in neurodegenerative diseases (Allan and Rothwell, 2003; Allan et al., 2005; Basu et al., 2004; Emsley et al., 2007, 2008; Lucas et al., 2006). Inhibition of IL-1 function by the naturally occurring, selective and potent antagonist IL-1RA has therapeutic promise in preventing damage in a range of inflammatory and autoimmune disorders including rheumatoid arthritis (Furst, 2004) and psoriasis.

rhIL-1RA also demonstrated benefit in preclinical studies on experimentally induced ischemic, excitotoxic, and traumatic brain insults in rodents (Pinteaux et al., 2006; Touzani et al., 1999) and potential in early clinical trials (Emsley et al., 2005). However, little is known about the biodistribution, pharmacokinetics and metabolism of rhIL-1RA so that brain penetration may be a key issue in its potential development as a therapeutic agent in brain traumatisms.

Pharmacokinetic modeling of rhIL-1RA administered intravenously in patients with subarachnoid haemorrhage (SAH) (Clark

\footnotetext{
* Corresponding author. Tel.: +33247367651; fax: +33247498830.

E-mail address: cprenant@cyclopharma.fr (C. Prenant).

${ }^{1}$ Present address: Cyclopharma, CERRP, 1-3 rue Germaine Richier, Tours 37100 , France.
}

et al., 2008) reported that it crossed significantly, but slowly into the CSF. However, the CSF concentrations achieved were similar to or higher than those found to be neuroprotective in rodents (Clark et al., 2008). A potential limitation of this work, as noted by the authors, is that the concentration of proteins in the CSF of patients may not reflect the concentration in the local brain environment.

Limited pharmacokinetics, tissue distribution, and elimination studies of IL-1RA in rats using ${ }^{35} \mathrm{~S}$-IL-1RA has been reported (Kim et al., 1995). Moreover, IL-1RA, radiolabelled with iodine-123, has been evaluated as a scintigraphic imaging marker of infection in a rabbit model but showed relatively poor imaging characteristics in term of both resolution and sensitivity (Van der Laken et al., 1998). In contrast, positron emission tomography (PET) has proved useful to study the pharmacokinetics and biodistribution of labeled peptides and proteins (Grierson et al., 2004; Haubner et al., 2001; Kramer-Marek et al., 2008). This led us to develop a radiolabeling method for rhIL-1RA, based on fluorine-18, for use with PET in order to better study the pharmacokinetics of this molecule with respect to brain uptake and metabolism.

Among the approaches investigated for fluorine-18 labeling of proteins using $\left[{ }^{18} \mathrm{~F}\right]$ fluoride, ${ }^{18} \mathrm{~F}$-acylation using $4-\left[{ }^{18} \mathrm{~F}\right]$ fluorobenzoyl moiety (Kramer-Marek et al., 2008; Okarvi, 2001) and chemoselective reactions of $4-\left[{ }^{18} \mathrm{~F}\right]$ fluorobenzaldehyde $\left(\left[{ }^{18} \mathrm{~F}\right] \mathrm{FB}-\right.$ $\mathrm{CHO}$ ) with peptide functionalized with a hydrazine or a aminooxy group producing respectively oxime and hydrazone have been extensively used (Cheng et al., 2008; Wester and Schottelius, 2007). The drawback of the labeling approaches using 
4- $\left[{ }^{18} \mathrm{~F}\right]$ fluorobenzoyl moiety is the lengthy, time-consuming multi-step preparation, involving a HPLC purification, of the ${ }^{18} \mathrm{~F}$ labeling agents. Peptide labeling approaches using the highly lipophilic $\left[{ }^{18} \mathrm{~F}\right] \mathrm{FB}-\mathrm{CHO}$ require the use of an organic co-solvent such as DMSO; furthermore, preparation of $\left[{ }^{18} \mathrm{~F}\right] \mathrm{FB}-\mathrm{CHO}$ involves a step of purification using HPLC or solid phase extraction. Another labeling method for IL-1RA was therefore attempted: reductive $\left[{ }^{18} \mathrm{~F}\right]$ fluoroethylation of free amino groups ( $\varepsilon$-amino group of lysine residues or amino-terminal residues) using $\left.{ }^{18} \mathrm{~F}\right]$ fluoroacetaldehyde (Prenant et al., 2008).

Reductive alkylation is a well-established method for the chemical modification of amino groups in proteins with minimal perturbation in their structure and function. The method is rapid and employs mild conditions, it has little effect on the physical chemical properties, only a slight change in the $p K a$ of the $\varepsilon$ monoalkylamino groups which are generally slightly more basic than the corresponding primary amino groups (Means and Feeney, 1995). Means (1977) has shown that when using acetaldehyde only the corresponding monoalkylated lysine is produced. Moreover, reductive alkylation of protein amino groups with small carbonyl compounds like formaldehyde or acetaldehyde cause a minimal disturbance of existing electrostatic interactions. Larger and generally more hydrophobic carbonyl compounds should, however, increase both the bulk and hydrophobicity of the amino group and reduce its ability to form hydrogen bonds (Means, 1977).

The choice of the reducing agent is crucial, Jentoft and Dearborn (1979) and Geoghegan et al. (1981) have applied the reductive methylation to different proteins using $\left[{ }^{12} \mathrm{C}\right],\left[{ }^{13} \mathrm{C}\right]$ and $\left[{ }^{14} \mathrm{C}\right]$ formaldehyde and showed that using sodium cyanoborohydride instead of sodium borohydride prevent aldehydes or ketones reduction, inter or intramolecular bridges formation, disulfide bond reductions or labile peptide bonds cleavage. This method has been used for carbon-11 labeling with [ $\left.{ }^{11} \mathrm{C}\right]$ formaldehyde of fibrinogen (Straatmann and Welch, 1975), and concanavalin A (Berger et al., 1984).

The mechanism for reductive $\left[{ }^{18} \mathrm{~F}\right]$ fluoroethylation of a free amino group of the IL-1RA involves the formation of an imine intermediate, the reduction of which yields the corresponding $\left[{ }^{18}\right.$ F]fluoroethyllysine (Fig. 1).

Radiolabeling was carried out in a remotely controlled experimental rig. The hydrophilicity and high reactivity with amino groups of $\left[{ }^{18} \mathrm{~F}\right]$ fluoroacetaldehyde in reductive alkylation conditions makes it a good reagent for protein radiolabeling by targeting free amino groups producing $N-\left[{ }^{18} \mathrm{~F}\right]$ fluoroethyl derivatives. The small size of the $\left[{ }^{18} \mathrm{~F}\right]$ fluoroethyl substituent is expected to have little impact on the rhIL-1RA integrity. Nevertheless as one of the nine lysine moieties on IL-1RA has been identified as important for receptor interaction (Evans et al., 1995), binding properties of the $\left[{ }^{18} \mathrm{~F}\right]$ IL-1RA were assayed using rat brain sections and autoradiography.

\section{Materials and methods}

\subsection{Remotely controlled radiosynthesis set-up}

The remotely controlled radiosynthesis experimental rig was set up in a lead-shielded fume-cupboard (Fig. 2). The core of the radiosynthesis set-up was comprised of three remotely controlled six-port/two-position electrically activated Valco valves (Thames Restek UK Ltd., UK). [ $\left.{ }^{18} \mathrm{~F}\right]$ Fluoroacetaldehyde production was carried out in Wheaton borosilicate screw-top V-vials, capacity $3.0 \mathrm{ml}$, with open-top cap and PTFE-faced silicon septum (SigmaAldrich, UK) using a home-made, temperature-regulated block heater, equipped with a magnetic stirrer and cooled with compressed air via a valve manually operated from outside the fume-cupboard. Reagents were added from outside the fumecupboard via two shut-off, low-pressure, valves from Upchurch (Sigma-Aldrich, UK). The labeling of rhIL-1RA was carried out in a $1.5 \mathrm{ml}$ microtube with attached screw cap (Sigma-Alrich, UK) using a digital block heater (Jencons Scientific, UK). The produced $\left[{ }^{18} \mathrm{~F}\right]$ rhIL-1RA was injected through a low protein-binding Pall Acrodisc ${ }^{\circledR}$ syringe filter ( $13 \mathrm{~mm}$ diameter, $0.2 \mu \mathrm{m}$ pore size) onto a $5 \mathrm{ml} \mathrm{HiTrap}{ }^{\mathrm{TM}}$ desalting column (GE Healthcare, UK) for purification using a programmable syringe pump model ALADDIN-220 (World Precision Instruments, UK). Radioactivity in reaction vials was monitored using a Ratemeter Mini 900 (Thermo Electron Corporation, UK). [ $\left.{ }^{18} \mathrm{~F}\right] \mathrm{rhIL}-1 \mathrm{RA}$ and other radioactive fractions collected after separation on the HiTrap column were measured on a Capintec CRC-15R.

\subsection{Chemicals}

Solvents were purchased from Sigma-Aldrich and were used without further purification. The rhIL-1RA, Anakinra ${ }^{\circledR}\left(\right.$ Kineret $\left.^{\circledR}\right)$, was kindly provided by Amgen (Thousand Oaks, CA, USA). Kineret ${ }^{\circledR}$ is a recombinant, methionylated, nonglycosylated synthetic form of the human interleukin-1 receptor antagonist (IL-1RA). It was provided as a solution formulated for injection consisting of $100 \mathrm{mg}$ of Anakinra, $1.29 \mathrm{mg}$ of sodium citrate, $5.48 \mathrm{mg}$ sodium chloride, $0.12 \mathrm{mg}$ disodium EDTA, and $0.70 \mathrm{mg}$ polysorbate 80 in $1 \mathrm{~mL}$ water for injection, USP ( $\mathrm{pH} 6.5$ at room temperature). $\left[{ }^{18} \mathrm{~F}\right]$ Fluoride was produced via the ${ }^{18} \mathrm{O}(\mathrm{p}, \mathrm{n}){ }^{18} \mathrm{~F}$ nuclear reaction by $16.4 \mathrm{MeV}$ proton bombardment of an isotopically enriched $\left[{ }^{18} \mathrm{O}\right]$ water target $\left(95-97 \% \mathrm{H}_{2}^{18} \mathrm{O}\right.$ water enrichment) using a GE PETtrace cyclotron.

\subsection{Radiochemistry}

\subsubsection{Production of $\left[{ }^{18}\right.$ Flpotassium fluoride}

The three electrovalves in the experimental rig (Fig. 2) were set in position $\mathrm{A}$ at initial time of the synthesis, aqueous $\left[{ }^{18} \mathrm{~F}\right]$ fluoride solution ( $2 \mathrm{ml}, 1.73-3.42 \mathrm{GBq}$ ) was sent from the cyclotron target onto a QMA cartridge, in the carbonate form. Electrovalve 1 was subsequently switched to position $\mathrm{B}$ and $\left[{ }^{18} \mathrm{~F}\right] \mathrm{KF}$ was eluted from the QMA with $1.1 \mathrm{mg}(8 \mu \mathrm{mol})$ potassium carbonate and $10 \mathrm{mg}$ $(26.5 \mu \mathrm{mol})$ of $4,7,13,16,21,24$-hexaoxa-1,10-diazabicyclo[8,8,8]hexacosane (Kryptofix 222) in $0.5 \mathrm{ml}$ water, added from shut-off valve 1 , into the reactor. Electrovalve 1 was subsequently switched back to position $\mathrm{A}$ and $1 \mathrm{ml}$ of acetonitrile was added from shut-off valve 1 . Temperature of the heater was set to $110{ }^{\circ} \mathrm{C}$ and the mixture was then dried under nitrogen for 5 mins. This drying step was repeated twice with $0.8 \mathrm{ml}$ of acetonitrile after what the heater was cooled to $30^{\circ} \mathrm{C}$.

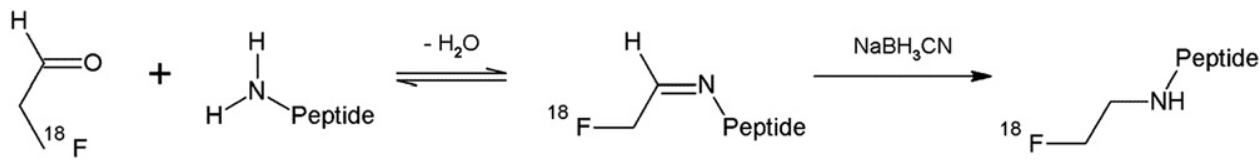

Fig. 1. Reductive $\left[{ }^{18} \mathrm{~F}\right]$ fluoroethylation of the IL-1RA with $\left[{ }^{18} \mathrm{~F}\right]$ fluoroacetaldehyde. 


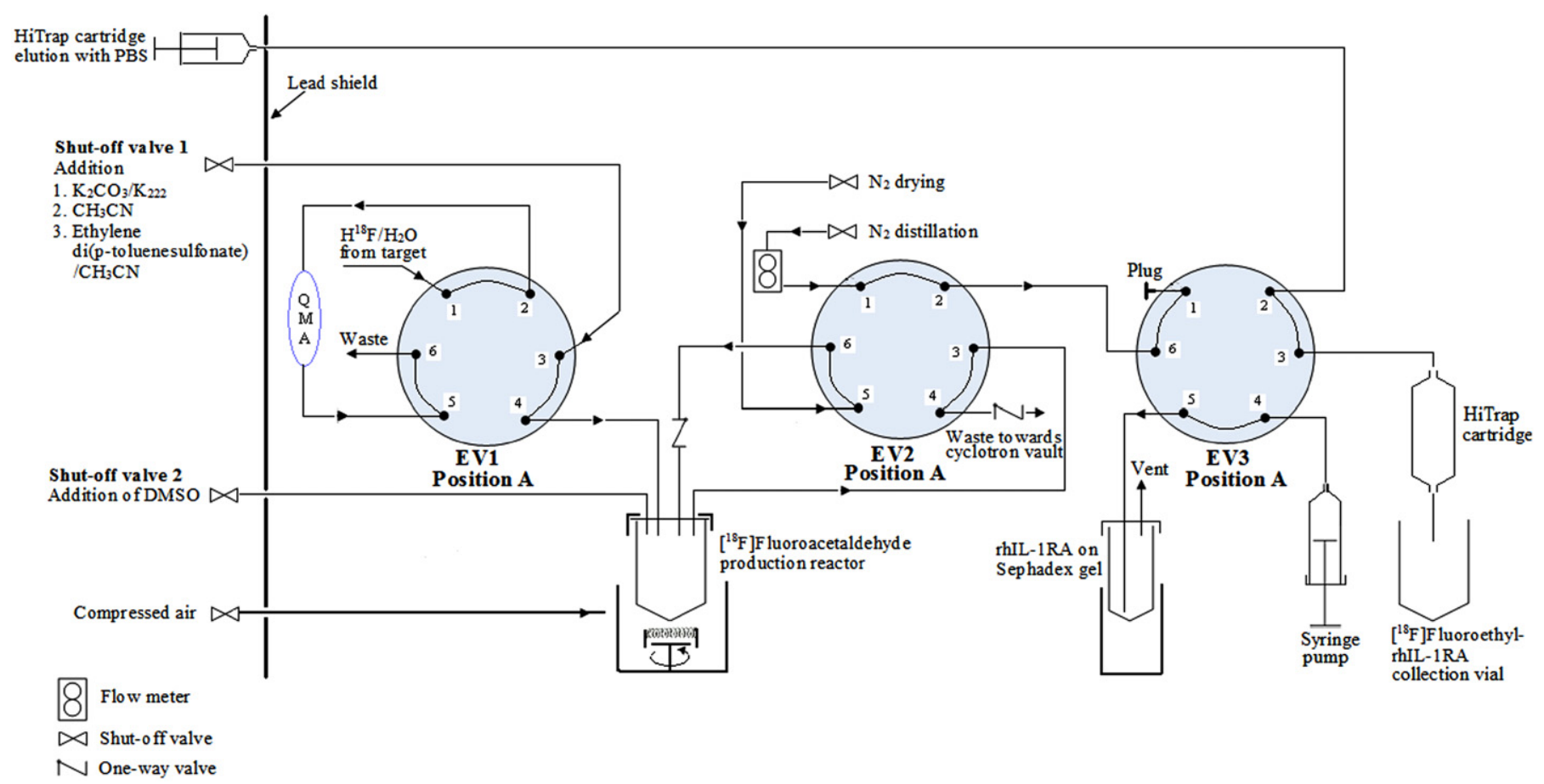

Fig. 2. Remotely controlled radiosynthesis experimental rig for $\left[{ }^{18} \mathrm{~F}\right]$ rhIL-1RA production.

\subsection{2. $\left[{ }^{18}\right.$ F]Fluoroethyltosylate}

A solution of ethylene di-p-toluenesulphonate, $5 \mathrm{mg}$ $(13.5 \mu \mathrm{mol})$ in $0.3 \mathrm{ml}$ acetonitrile was added to the dried $\left[{ }^{18} \mathrm{~F}\right]$ potassium fluoride/Kryptofix complex through shut-off valve 1. Electrovalve 2 was subsequently switched to position $B$, the heater was set to $90{ }^{\circ} \mathrm{C}$, and the mixture was heated for $8 \mathrm{~min}$.

\subsection{3. $\left[{ }^{18}\right.$ F]Fluoroacetaldehyde}

The heater was subsequently cooled to $60^{\circ} \mathrm{C}$, electrovalve 2 switched to position $\mathrm{A}$ and acetonitrile was evaporated under nitrogen. Evaporation was completed within $3 \mathrm{~min}$ after which electrovalves 2 and 3 were switched to position B, anhydrous DMSO $(0.2 \mathrm{ml})$ was added through shut-off valve 2 and the temperature of the heater was set to $150{ }^{\circ} \mathrm{C}$. Around 1 min after the heater had reached this temperature $\left[{ }^{18} \mathrm{~F}\right]$ fluoroacetaldehyde started to distil conveyed by nitrogen $(7-8 \mathrm{ml} / \mathrm{min})$.

\subsection{4. $\left[{ }^{18} \mathrm{~F}\right] \mathrm{rhIL}-1 \mathrm{ra}$}

Distilled $\left[{ }^{18} \mathrm{~F}\right]$ fluoroacetaldehyde was trapped into a microtube containing the rhIL-1RA in suspension in a Sephadex ${ }^{\mathbb{R}}$ gel to avoid foaming of the protein solution. The gel was made by addition of $20 \mu \mathrm{l}(2 \mathrm{mg})$ of a solution of the rhIL-1RA formulated for injection $(100 \mathrm{mg} / \mathrm{ml})$ and $40 \mu \mathrm{l}$ of a $0.25 \mathrm{M}$ solution of sodium cyanoborohydride in citrate buffer (citric acid, $\sim 0.060 \mathrm{M}$, sodium hydroxide, $\sim 0.16 \mathrm{M}, \mathrm{pH}=6$ ), onto dry Sephadex ${ }^{\circledR} \mathrm{G}-50$ (6 mg). After $8 \mathrm{~min}$ all the $\left[{ }^{18} \mathrm{~F}\right]$ fluoroacetaldehyde was distilled, as monitored by a radioactivity detector. The microtube was subsequently heated at $38{ }^{\circ} \mathrm{C}$ for $45 \mathrm{~min}$ after which PBS ( $\left.1 \mathrm{ml}, \mathrm{pH} 7.2\right)$ was added to the gel via the syringe pump. This addition was followed by the withdrawing of suspension via a programmed step on the syringe pump, after which electrovalve 3 was switched to position A. The reaction mixture was then injected by the syringe pump onto a HiTrap ${ }^{\mathbb{R}}$ column via a low-protein-binding filter for purification. After injection into the column electrovalve 3 was switched back to position A and the HiTrap ${ }^{\mathbb{R}}$ was eluted with PBS using a syringe from outside the fume-cupboard. The first $0.5 \mathrm{ml}$ were sent to waste, $\left[{ }^{18} \mathrm{~F}\right] \mathrm{rhIL}-1 \mathrm{RA}$ eluted within the following $2 \mathrm{ml}$ fraction which was collected, weighted, the radioactivity measured and a sample $(20 \mu \mathrm{l})$ analyzed for QC.

$\left[{ }^{18} \mathrm{~F}\right]$ rhIL-1RA was prepared within $100 \mathrm{~min}$, from the time of the addition of the ${ }^{18} \mathrm{~F}^{-}$, with $7.1-24.2 \%$ radiochemical yield (mean value $11.4 \pm 4.1 \%$, based on seventeen syntheses and decay corrected). $\left[{ }^{18} \mathrm{~F}\right] \mathrm{rhIL}-1 \mathrm{ra}, 60.31-310.8 \mathrm{MBq}$ (uncorrected for decay) was thus collected as a $2 \mathrm{~mL}$ fraction. The specific activity ranged from 913.15 to $5040.20 \mathrm{MBq} / \mu \mathrm{mol}$ at the end of synthesis. From $2 \mathrm{mg}$ of initial rhIL-1RA, $1.1-1.9 \mathrm{mg}$ was recovered as a mixture of labeled and unlabelled protein.

\subsection{Quality control}

\subsubsection{SE-HPLC}

QC analyses of rhIL-1RA and $\left[{ }^{18} \mathrm{~F}\right]$ rhIL-1RA were made by size exclusion high-performance liquid chromatography (SE-HPLC) performed on a HPLC Shimadzu prominence system operated using a LabLogic software Laura 3 and configured with a CBM20 A controller, an LC-20AB solvent delivery system and a SPD20 A dual wavelength absorbance detector set at 254 and $235 \mathrm{~nm}$. The system was equipped with a Superdex ${ }^{\circledR}$ Gel Filtration Column Peptide HR10/300 GL (GE Healthcare, UK) eluted with PBS at a $1 \mathrm{ml} / \mathrm{min}$ flow-rate. Radioactivity was monitored with a radioHPLC Bioscan Flowcount B-FC 3100 detector.

\subsubsection{SDS PAGE}

Fifteen percent acrylamide gels were cast with a $4 \%$ acrylamide stacking gel using a Mini Protean III system (Bio-Rad). $5 \mu \mathrm{l}$ Prestained Precision Plus Protein Standards (BioRad, UK, Catalogue number 161-0375) were loaded into lane one and a sample of ca $50 \mathrm{ng}$ of mixed radiolabelled and unlabelled protein from the $1.1-1.9 \mathrm{mg}$ recovered fraction of rhIL-1RA diluted in $2 \mathrm{X}$ Laemlli Buffer (4\% sodium dodecyl sulphate (SDS), 20\% glycerol, $120 \mathrm{mM}$ Tris. $\mathrm{Cl}$ pH 6.8, 0.01\% Bromophenol blue, 10\% 2-mercaptoethanol) was loaded into lane 2 . They were run at $30 \mathrm{~mA}$ until the dye 
appeared at the bottom at which point they were removed and fixed by immersion in $45 \%$ deionised water, $45 \%$ methanol and $10 \%$ acetic acid. Gels of radiolabelled rhIL-1RA were then photographed, sealed in clingfilm and placed into an imaging cassette. Autoradiography was performed using a Fujifilm BioImaging Analyzer BAS-1800II (FujiFilm UK Ltd., UK) and data were analyzed using Advanced Image Data Analyzer software (Raytest, Straubenhardt, Germany). Radiolabelled protein was sized by overlaying the photograph onto the autoradiogram. Gels of unlabelled rhIL-1RA were stained with Coomassie Brilliant Blue (PhastGel $^{\mathrm{TM}}$ Blue R, GE Healthcare, UK).

\subsection{In vitro binding of $\left[{ }^{18} \mathrm{~F}\right]$ rhIL-1RA to IL-1 receptor}

An in vitro assay was performed to investigate the ability of the produced $\left[{ }^{18} \mathrm{~F}\right]$ rhIL-1RA to bind to the IL- 1 receptors. The assay was conducted using rat brain slices $(n=3 ; 9-11$ brain sections per rat). Binding of the labeled protein was detected by autoradiography.

\subsubsection{Brain sample preparation}

Adult, male, Sprague-Dawley rats (250-300 g body-weight) were used to perform autoradiography experiments. The animals were housed in a controlled environment of $12 \mathrm{~h}$ light/dark cycle (08:00/20:00 h) at $22{ }^{\circ} \mathrm{C}$. Transient focal cerebral ischemia (60 min) was induced in rats by the intraluminal thread method, as described previously (Longa et al., 1989). 7 days post-MCAO, rats were killed by anesthetic overdose with isoflurane and decapitated. Brains were removed quickly and frozen in cooled $\left(-40^{\circ} \mathrm{C}\right)$ isopentane. Coronal brain sections were cut serially ( $20 \mu \mathrm{m}$ at $1.2 \mathrm{~mm}$ intervals between each level) on frozen brains by cryostat. All procedures were performed in accordance with UK legislation under the 1986 Animals (Scientific Procedures) Act and by approved protocols (Home Office Project License Number 40/3076).

\subsubsection{Binding assay}

Specific binding of $\left[{ }^{18} \mathrm{~F}\right]$ rhIL-1RA was determined by comparing the level of total binding (specific and non-specific binding) and the level of non-specific binding in matched rat brain sections. To determine total binding, slices of healthy rat brains were pre-incubated in $10 \mathrm{mM}$ phosphate buffer saline (PBS) at $4{ }^{\circ} \mathrm{C}$ for $5 \mathrm{~min}$, then incubated in solutions of different concentra- tions of the $\left[{ }^{18} \mathrm{~F}\right]$ rhIL-1RA $(10,20$, and $40 \mathrm{nM}$ in PBS, $10 \mathrm{mM}$ at room temperature). After $30 \mathrm{~min}$ incubation, the slices were washed three times 3 min in PBS to remove unbound radiolabelled protein, then quickly rinsed in cold distilled water, before exposition to PhosphorImager plates overnight. To determine non-specific binding, a second set of brain sections were treated as described above but in a solutions containing $\left[{ }^{18} \mathrm{~F}\right] \mathrm{rhIL}-1 \mathrm{RA}(10$, 20 , and $40 \mathrm{nM}$ ) and one thousand-fold excess (i.e. 10-40 $\mu \mathrm{M}$ ) of non-radiolabelled rhIL-1RA. Radiolabelled rhIL-1RA that was not displaced by non-radiolabelled rhIL-1RA accounted for the nonspecifically bound. Specific binding was calculated by subtracting the non-specific from total binding of $\left[{ }^{18} \mathrm{~F}\right]$ rhIL-1RA.

\section{Result and discussion}

Although targeting $\varepsilon$-amino groups of lysine moieties randomly could be considered as the drawback of this labeling approach, with $\left[{ }^{18} \mathrm{~F}\right]$ fluoroacetaldehyde the size of the added $\left[{ }^{18} \mathrm{~F}\right]$ fluoroethyl substituent is small and should have little effect on the physical chemical properties and the structure of the protein allowing PET pharmacokinetic studies. In addition to its small size $\left[{ }^{18} \mathrm{~F}\right]$ fluoroacetaldehyde presents following advantages: first it is easily produced via a fast and simple procedure in a two-step, one-pot reaction using oxidation with DMSO of $\left[{ }^{18} \mathrm{~F}\right]$ fluoroethyltosylate; second it is simply extracted continuously by distillation from the reaction mixture sparing a purification step using HPLC or solid phase extraction and finally the highly hydrophilic aldehyde is efficiently trapped in a small volume of water $(<100 \mu \mathrm{l})$. Furthermore the mild labeling conditions, citrate buffer $\mathrm{pH} 6$ and low temperature $\left(38^{\circ} \mathrm{C}\right)$, make the purification of the radiolabelled protein straightforward. Purification of the $\left[{ }^{18} \mathrm{~F}\right] \mathrm{rhIL} 1-\mathrm{ra}$ was thus simply made by eluting the reaction mixture through a HiTrap desalting column. Analysis of the crude synthesis mixture by SE-HPLC using the radioactivity detector before purification on the HiTrap cartridge showed that it contained $\left[{ }^{18} \mathrm{~F}\right] \mathrm{rhIL}-1 \mathrm{RA}\left(R_{t}=12.2\right.$ $\mathrm{min})$, unreacted $\left[{ }^{18} \mathrm{~F}\right.$ fluoroacetaldehyde $\left(R_{t}=20 \mathrm{~min}\right)$ and a minor unidentified radioactive impurity $\left(R_{t}=24.2 \mathrm{~min}\right)$ (Fig. 3$)$. $\left[{ }^{18} \mathrm{~F}\right] \mathrm{rhIL}-$ $1 \mathrm{RA}$ accounted for $28-35 \%$ of the total radioactivity of the analyte of the synthesis mixture (yield based on three analyses). Identification of the second peak as $\left[{ }^{18} \mathrm{~F}\right]$ fluoroacetaldehyde was made by comparing the retention time with standard fluoracetaldehyde prepared as previously described (Prenant et al., 2008). The unidentified radioactive impurity may have resulted from

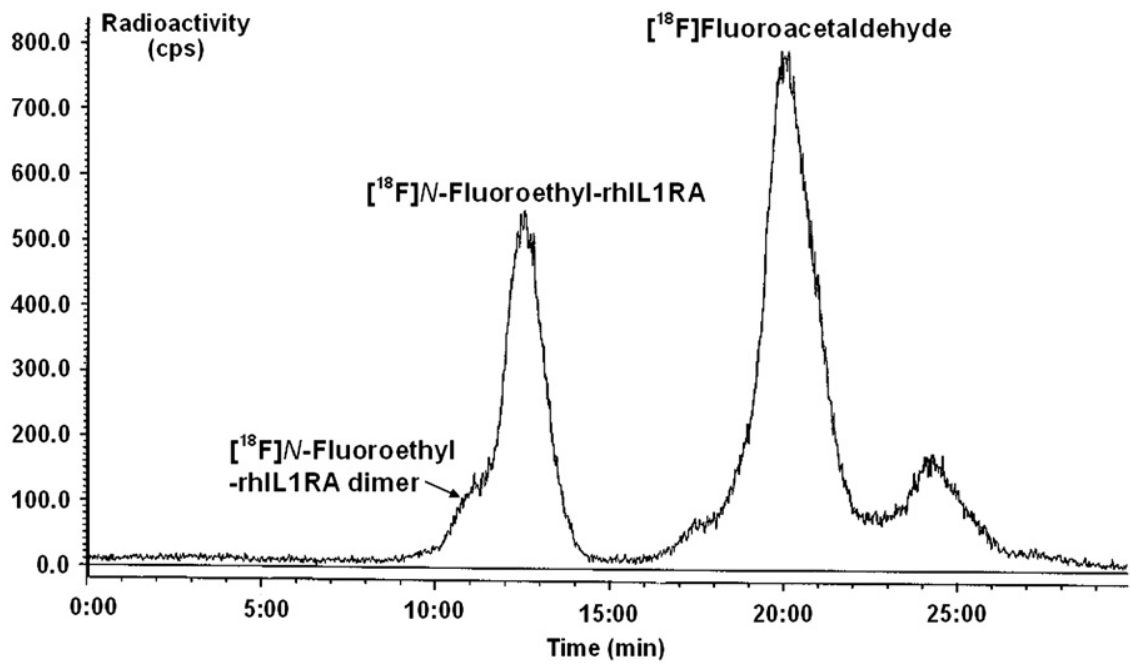

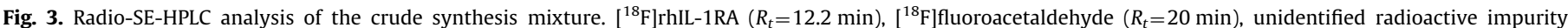
$\left(R_{t}=24.6 \mathrm{~min}\right)$. 
$\left[{ }^{18} \mathrm{~F}\right]$ fluoroacetaldehyde reduction to $\left[{ }^{18} \mathrm{~F}\right]$ fluoroethanol or the reaction of free cyanide ion released from sodium cyanoborohydride with $\left[{ }^{18} \mathrm{~F}\right]$ fluoroacetaldehyde to produce the cyanohydrin, lactonitrile (Gidley and Sanders, 1982). Both small molecules were sufficiently retained on the HiTrap column to allow the protein to be eluted as a pure compound under monomeric and dimeric form with a radiochemical purity, for the mixte two forms, over $95 \%$ in a small volume (2 ml). QC SE-HPLC analysis of the $\left[{ }^{18} \mathrm{~F}\right] \mathrm{rhIL}-1 \mathrm{RA}, \mathrm{UV}$ absorbance trace as well as the radioactivity trace (Fig. 4) showed two poorly resolved peaks. On the UV absorbance trace, the small peak at retention time 10.0 min preceding a larger one at retention time $11.8 \mathrm{~min}$, suggested the presence of a dimer. SDS-PAGE analysis of the labeled rhIL-1RA (Fig. 5) confirmed the presence of a minor dimeric fraction (faint band at approximately $35 \mathrm{kD}$ ), but most of the radioactivity migrated to a position consistent with a $17 \mathrm{kD}$ protein. Similarly, the SE-HPLC chromatogram of the reference rhIL-1RA showed two peaks (data not shown) nevertheless only a monomeric molecular weight was seen by SDS-PAGE (data not shown).

At relatively high concentrations (i.e. $100 \mathrm{mg} / \mathrm{ml}$ ), rhIL-1RA exists in a monomer-dimer equilibrium (Chang et al., 1996; Roy et al., 2005; Alford et al., 2008a, 2008b). Chang et al. (1996) have also shown that an irreversible dimer formed, that amounted to $8 \%$ of the total soluble protein, during storage for 2 months at $30{ }^{\circ} \mathrm{C}$ and this irreversible dimer was mostly dissociated during SDS-PAGE. Our radiolabeling method was applied to other proteins without producing dimerization (data not shown); thus, we cannot exclude the possibility that production of the dimer was caused during storage of the rhIL-1RA solution and the non-visualisation of unlabelled rhIL-1RA dimer by SDS-PAGE/ Coomassie staining was due to a lack of sensitivity of this technique.

Since expression of IL-1 receptors has been reported before in a rat and mouse brains (Parnet et al., 1994; French et al., 1999; Friedman, 2001), we choose to use autoradiography on rat brain sections to test whether we could observe any specific binding (displaceable) of our $\left[{ }^{18} \mathrm{~F}\right]$ radiolabelled IL-1RA. Specificity of binding was determined by displacement of the bound $\left[{ }^{18} \mathrm{~F}\right]$ rhIL-1RA by an excess of unlabelled rhIL-1RA on rat brain sections as measured by autoradiography (Fig. 6a).
Comparison of the total binding (Tot) and non-specific binding (NS) indicated that specific binding (Spe) of the radiolabelled $\left[{ }^{18} \mathrm{~F}\right]$ rhIL-1RA to IL-1 receptors accounted for $24-29 \%$ of total binding (Fig. 6b). Aware of the high concentrations of $\left[{ }^{18} \mathrm{~F}\right] \mathrm{rhIL}-$ 1RA (mixed with unlabelled) used for autoradiography when compared to the reported $K_{d}$ of IL-1RA for the IL- 1 receptors, we have tried to assess specific binding with lower concentrations of $\left[{ }^{18} \mathrm{~F}\right]$ rhIL-1RA (1 nM) using autoradiography and binding on cell membranes preparation; unfortunately, due to the relatively short half-life of fluorine-18 (when compared with iodine-125 for example), we could not detect any reliable signal on the PhophorImager plates or by $\gamma$-counting. Clearly, fluorine- 18 labeling of protein would not be the most convenient and appropriate technique to assess in vitro binding of a tracer to receptors expressed at very low levels such as the IL-1 receptors. In this study, exemplifying this new radiochemistry, the main aim of labeling rhIL-1RA was more to develop a tool to assess the

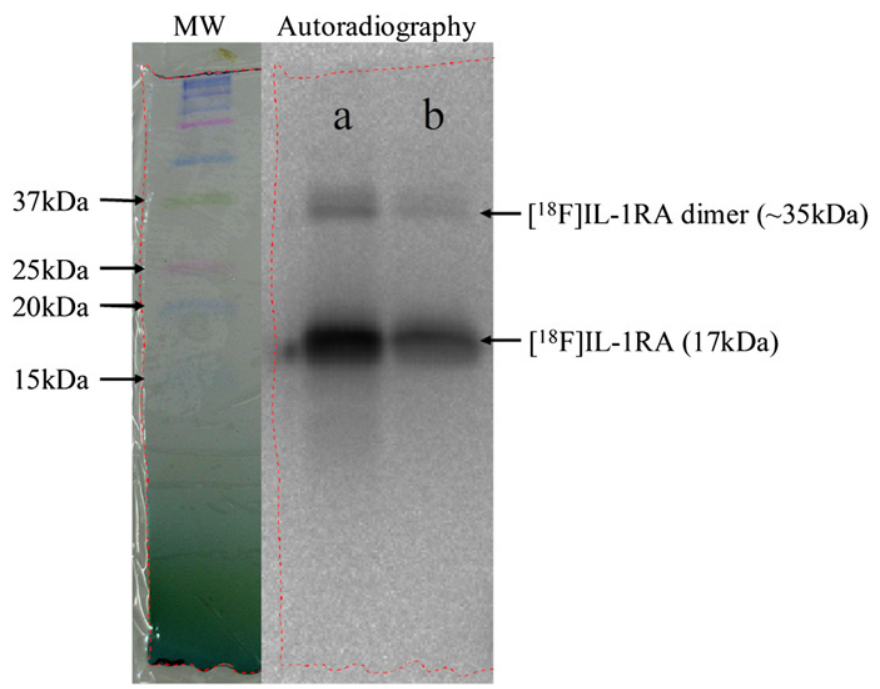

Fig. 5. PAGE analysis of the purified $\left[{ }^{18} \mathrm{~F}\right]$ rhIL-1RA (MW: molecular weight references loaded in the same lane than $\left[{ }^{18} \mathrm{~F}\right]$ rhIL-1RA (a)) and autoradiography (a: $1.1 \mu \mathrm{g}$ of rhIL-1RA $=17.8 \mathrm{kBq}$ in $20 \mu \mathrm{l}$; b: $0.1 \mu \mathrm{g}$ of rhIL-1RA $=2.2 \mathrm{kBq}$ in $20 \mu \mathrm{l}$ ).

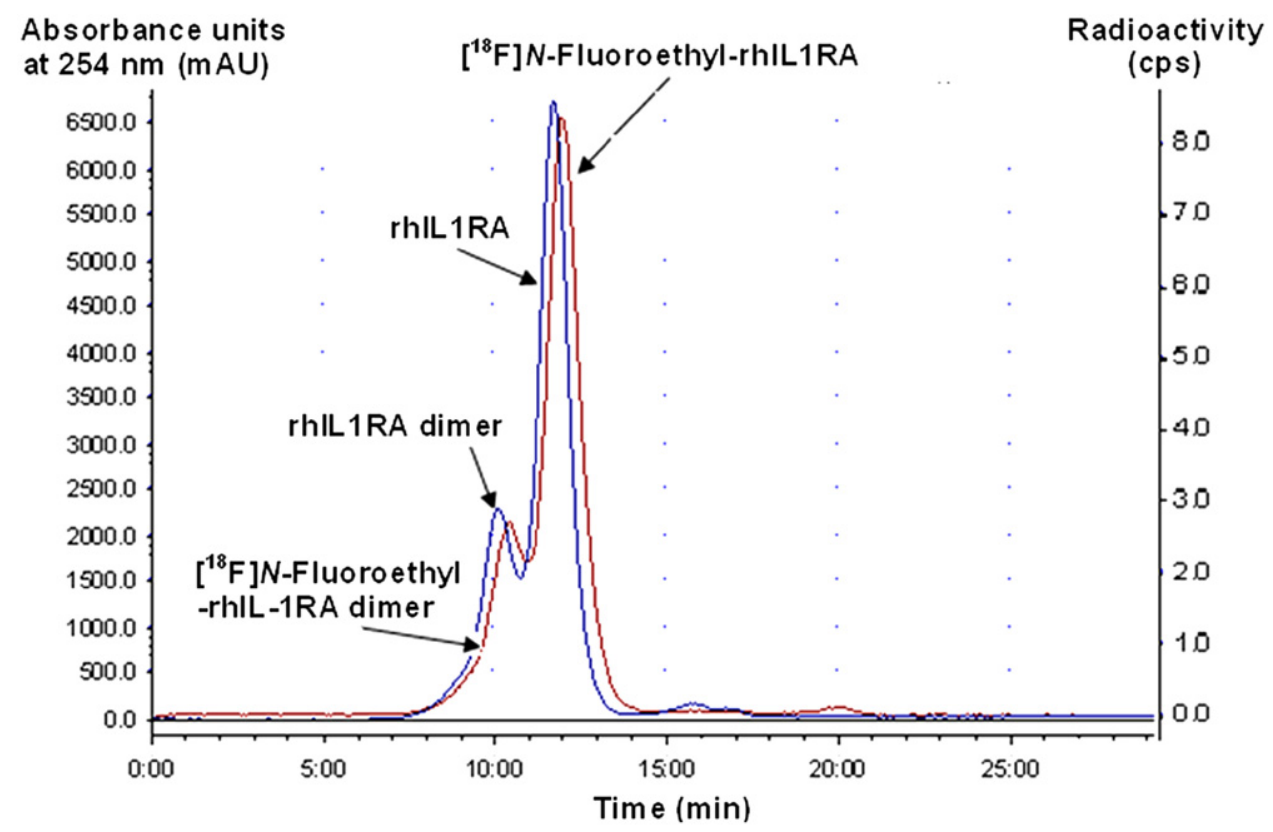

Fig. 4. QC of the purified $\left[{ }^{18} \mathrm{~F}\right]$ rhIL-1RA, SE-HPLC uv-trace and radio-trace. 
a

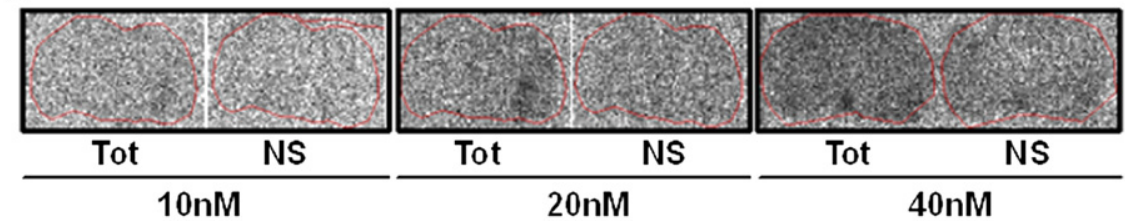

b Quantification of $\left[{ }^{18} \mathrm{~F}\right] \mathrm{rhIL1RA}$ : autoradiography

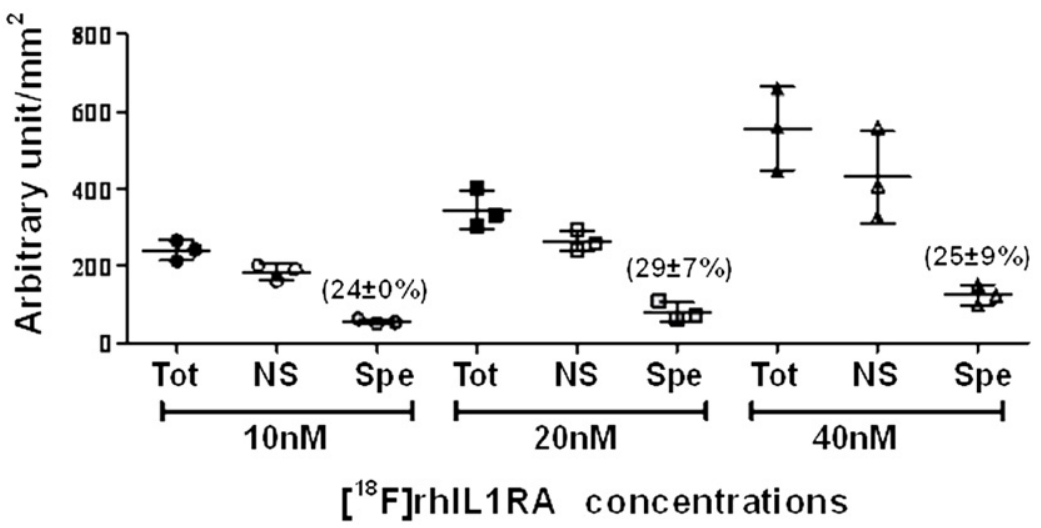

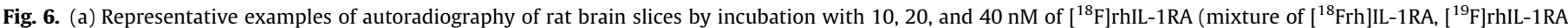

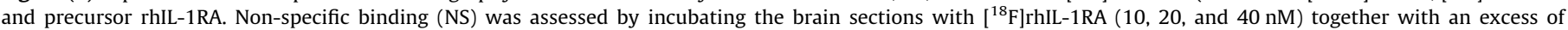

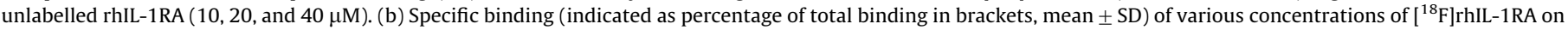
rat brain sections.

biodistribution and metabolisms of IL-1RA than its in vitro binding, especially when considering the high level of nonspecific binding observed here.

\section{Conclusion}

We describe here a simple method for radiolabeling of rhIL-1RA using $\left[{ }^{18} \mathrm{~F}\right]$ fluoroacetaldehyde. Radiosynthesis and purification, using a HiTrap ${ }^{\circledR}$ desalting column, were carried out in a remotely controlled experimental rig within $100 \mathrm{~min}$. The radiochemical yield was in the range $7.1-24.2 \%$ (mean value $11.4 \pm 4.1 \%$, decay-corrected, based on seventeen syntheses). Starting from 1.73 to $3.42 \mathrm{GBq}(64-126 \mathrm{mCi})$ of fluorine-18, 60.31-310.80 MBq (1.63-8.40 mCi) of $\left[{ }^{18} \mathrm{~F}\right] \mathrm{rhIL}-1 \mathrm{RA}$ were produced. Moreover, we showed that $\left[{ }^{18} \mathrm{~F}\right] \mathrm{rhIL}-1 \mathrm{RA}$ retained binding potency in a rat brain binding assay. Therefore, this method allowed us to produce $\left[{ }^{18} \mathrm{~F}\right] \mathrm{rhIL}-1 \mathrm{RA}$ on a small scale with sufficient radiochemical purity and specific activity to enable pharmacokinetic studies in small animals using PET and the investigation of the relevance of rhIL-1 $\mathrm{ra}$ as a therapeutic agent in brain traumatisms. Moreover, this radiolabeling technique can be applied to any peptide and protein with lysine moieties available for reaction with $\left[{ }^{18} \mathrm{~F}\right]$ fluoroacetaldehyde, thus providing another method for the radiolabeling of proteins of interest/therapeutic agents, for the assessment of both their pharmacokinetics and biodistribution or their use as imaging biomarkers.

\section{Acknowledgements}

The authors would like to thank AMGEN for providing the rhIL1RA (Kineret ${ }^{\circledR}$ ) (MTA 200613204-001). C. Prenant, M. Fairclough and this project were funded by the Wolfson Molecular Imaging Centre, University of Manchester. C. Cawthorne was funded by
Cancer Research UK (Grant C153/A4331). N. Rothwell and $\mathrm{H}$. Boutin are funded by the Medical Research Council (UK).

\section{References}

Alford, J.R., Kendrick, B.S., Carpenter, J.F., Randolph, T.W., 2008a. High concentration formulations of recombinant human interleukin-1 receptor antagonist: II. Aggregation kinetics. J. Pharm. Sci. 97, 3005-3021.

Alford, J.R., Kwok, S.C., Roberts, J.N., Wuttke, D.S., Kendrick, B.S., Carpenter, J.F., Randolph, T.W., 2008b. High concentration formulations of recombinant human interleukin-1 receptor antagonist: I. Physical characterization. J. Pharm. Sci. 97, 3035-3050.

Allan, S.M., Rothwell, N.J., 2003. Inflammation in central nervous system injury. Philos. Trans. R. Soc. London B Biol. Sci. 358, 1669-1677.

Allan, S.M., Tyrrell, P.J., Rothwell, N.J., 2005. Interleukin-1 and neuronal injury. Nat. Rev. Immunol. 5, 629-640.

Basu, A., Krady, J.K., Levison, S.W., 2004. Interleukin-1: a master regulator of neuroinflammation. J. Neurosci. Res. 78, 151-156.

Berger, G., Mazière, M., Prenant, C., Sastre, J., Comar, D., 1984. 11C Labelling of a protein: concanavalin A. Int. J. Appl. Radiat. Isot. 35, 81-83.

Chang, B.S., Beauvais, R.M., Arakawa, T., Narhi, L.O., Dong, A., Aparisio, D.I., Carpenter, J.F., 1996. Formation of an active dimer during storage of interleukin-1 receptorantagonist in aqueous solution. Biophys. J. 71, 3399-3406.

Cheng, Z., De Jesus, O.P., Namavari, M., De, A., Levi, J., Webster, J.M., Zhang, R., Lee B., Syud, F.A., Gambhir, S.S., 2008. Small-animal pet imaging of human epidermal growth factor receptor type 2 expression with site specific $18 \mathrm{~F}$ labeled protein scaffold molecules. J. Nucl. Med. 49, 804-813.

Clark, S.R., McMahon, C.J., Gueorguieva, I., Rowland, M., Scarth, S., Georgiou, R Tyrell, P.J., Hopkins, S.J., Rothwell, N.J., 2008. Interleukin-1 receptor antagonist penetrates human brain at experimentally therapeutic concentrations. J. Cerab. Blood Flow Metab., 1-8.

Dinarello, C.A., 1988. Biology of interleukin-1. FASEB J. 2, 108-115.

Dinarello, C.A., 1997. Interleukin-1. Cytokine Growth Factor Rev. 8, 253-265.

Emsley, H.C.A., Smith, C.J., Georgiou, R.F., Vail, A., Hopkins, S.J., Rothwell, N.J., Tyrrell, P.J., 2005. A randomized phase II study of interleukin-1 receptor antagonist in acute stroke patients. J. Neurol. Neurosurg. Psychiatry 76, 1366-1372.

Emsley, H.C., Smith, C.J., Gavin, C.M., Georgiou, R., Vail, A., Barberan, E.M., Illingworth, K., Scarth, S., Wickramasinghe, V., Hoadley, M.E., Rothwell, N.J., Tyrrell, P., opkins, S.J., 2007. Clinical outcome following acute ischaemic stroke relates to both activation and autoregulatory inhibition of cytokine production. BMC Neurol. 7, 5 .

Emsley, H.C.A., Smith, C.J., Tyrrell, P.J., Hopkins, S.J., 2008. Inflammation in acute ischemic stroke and its relevance to stroke critical care. Neurocrit. Care 9, 125-138. 
Evans, R.J., Bray, J., Childs, J.D., Vigers, G.P., Brandhuber, B.J., Skalicky, J.J., Thompson, R.C., Eisenberg, S.P., 1995. IL-1RA mapping receptor binding sites in interleukin (IL)-1 receptor antagonist and IL-1 beta by site-directed mutagenesis. Identification of a single site in IL-1RA and two sites in IL-1 beta. J. Biol. Chem. 270, 11477-11483.

French, R.A., Van Hoy, R.W., Chizzonite, R., Zachary, J.F., Dantzer, R., Parnet, P. Bluthé, R.-M., Kelley, K.W., 1999. Expression and localization of p80 and p68 interleukin- 1 receptor proteins in the brain of adult mice. J. Neuroimmunol 93, 194-202.

Friedman, W.J., 2001. Cytokines regulate expression of the type 1 interleukin-1 receptor in rat hippocampal neurons and glia. Exp. Neurol. 168, 23-31.

Furst, D.E., 2004. Anakinra: review of recombinant human interleukin-1 receptor antagonist in the treatment of rheumatoid arthritis. Clin. Ther. 26, 1960-1975.

Geoghegan, K.F., Cabacungan, J.C., Dixon, H.B., Feeney, R.E., 1981. Alternative reducing agents for reductive methylation of amino groups in proteins. Int. J. Pept. Protein Res. 17, 345-352.

Gidley, M.J., Sanders, J.K.M., 1982. Reductive methylation of proteins with sodium cyanoborohydride. Biochem. J. 203, 331-334

Grierson, J.R., Yagle, K.J., Eary, J.F., Tait, J.F., Gibson, D.F., Lewellen, B., Link, J.M. Krohn, K.A., 2004. Production of [18F]fluoroannexin for imaging apoptosis with PET. Bioconjugate Chem. 15, 373-379.

Haubner, R., Wester, H.J., Weber, W.A., Mang, C., Ziegler, S.I., Goodman, S.L., Senekowitsch-Schmidtke, R., Kessler, H., Schwaiger, M., 2001. Noninvasive imaging of $\alpha_{\mathrm{v}} \beta_{3}$ integrin expression using ${ }^{18} \mathrm{~F}$-labeled RGD-containing glycopeptide and positron emission tomography. Cancer Res. 61, 1781-1785.

Jentoft, N., Dearborn, D.G., 1979. Labeling of proteins by reductive methylation using sodium cyanoborohydride. J. Biol. Chem. 254, 4359-4365.

Kim, D.-C., Reitz, B., Carmichael, D.F., Bloedow, D.C., 1995. Kidney as a major clearance organ for recombinant human interleukin-i receptor antagonist. J. Pharm. Sci. 84, 575-580.

Kramer-Marek, G., Kiesewetter, D.O., Martiniova, L., Jagoda, E., Lee, S.B., Capala, J. 2008. [ ${ }^{18}$ F]FBEM-Z $Z_{\text {HER2 }}$-affibody molecule-a new molecular tracer fo in vivo monitoring of HER2 expression by positron emission tomography. Eur. J. Nucl. Med. Mol. Imaging 35, 1008-1018.
Longa, E.Z., Weinstein, P.R., Carlson, S., Cummins, R., 1989. Reversible middle cerebral artery occlusion without craniectomy in rats. Stroke 20, 84-91.

Lucas, S.-M., Rothwell, N.J., Gibson, R.M., 2006. The role of inflammation in CNS injury and disease. Br. J. Pharmacol. 147, S232-S240.

Means, G.E., 1977. Reductive alkylation of amino groups. Methods Enzymol. 47, 469-478.

Means, G.E., Feeney, R.E., 1995. Reductive alkylation of proteins. Anal. Biochem. $224,1-16$

Okarvi, S.M., 2001. Recent progress in fluorine-18 labelled peptide radiopharmaceuticals. Eur. J. Nucl. Med. 28, 929-938.

Parnet, P., Amindari, S., Wu, C., Brunke-Reese, D., Goujon, E., Weyhenmeyer, J.A., Dantzer, R., Kelley, K.W., 1994. Expression of type I and type II interleukin-1 receptors in mouse brain. Brain Res. Mol. Brain Res. 27, 63-70.

Pinteaux, E., Rothwell, N.J., Boutin, H., 2006. Neuroprotective actions of endogenous interleukin-1 receptor antagonist (IL-1ra) are mediated by glia. Glia 53, 551-556.

Prenant, C., Gillies, J., Bailey, J., Chimon, G., Jayson, G.C., Zweit, J., 2008. Synthesis of $\left[{ }^{18} \mathrm{~F}\right]$ fluoroacetaldehyde. Application to $\left[{ }^{18} \mathrm{~F}\right]$ fluoroethylation of benzylamine under reductive alkylation conditions. J. Label Compd. Radiopharm. 51, 262-267.

Roy, S., Jung, R., Kerwin, B.A., Randolph, T.W., Carpenter, J.F., 2005. Effects of benzyl alcohol on aggregation of recombinant human interleukin-1-receptor antagonist in reconstituted lyophilized formulations. J. Pharm. Sci. 94, 382-396.

Straatmann, M.G., Welch, M.J., 1975. A general method for labeling proteins with 11C. J. Nucl. Med. 16, 425-428.

Touzani, O., Boutin, H., Chuquet, J., Rothwell, N., 1999. Potential mechanisms of interleukin-1 involvement in cerebral ischaemia. J. Neuroimmunol. 100, 203-215.

Van der Laken, C.J., Boerman, O.C., Oyen, W.J.G., van de Ven, M.T.P., van der Meer, J.W.M., Corstens, F.H.M., 1998. Imaging of infection in rabbits with radioiodinated interleukin- 1 ( $\alpha$ and $\beta$ ), its receptor antagonist and a chemotactic peptide: a comparative study. Eur. J. Nucl. Med. 25, 347-352.

Wester, H.J., Schottelius, M., 2007. Fluorine-18 labeling of peptides and proteins. In: Schubiger, P.A., Lehmann, L., Friebe, M. (Eds.), PET Chemistry. The Driving Force in Molecular Imaging, Ernst Schering Foundation Symposium Proceedings, vol. 62, pp. 79-111. 